
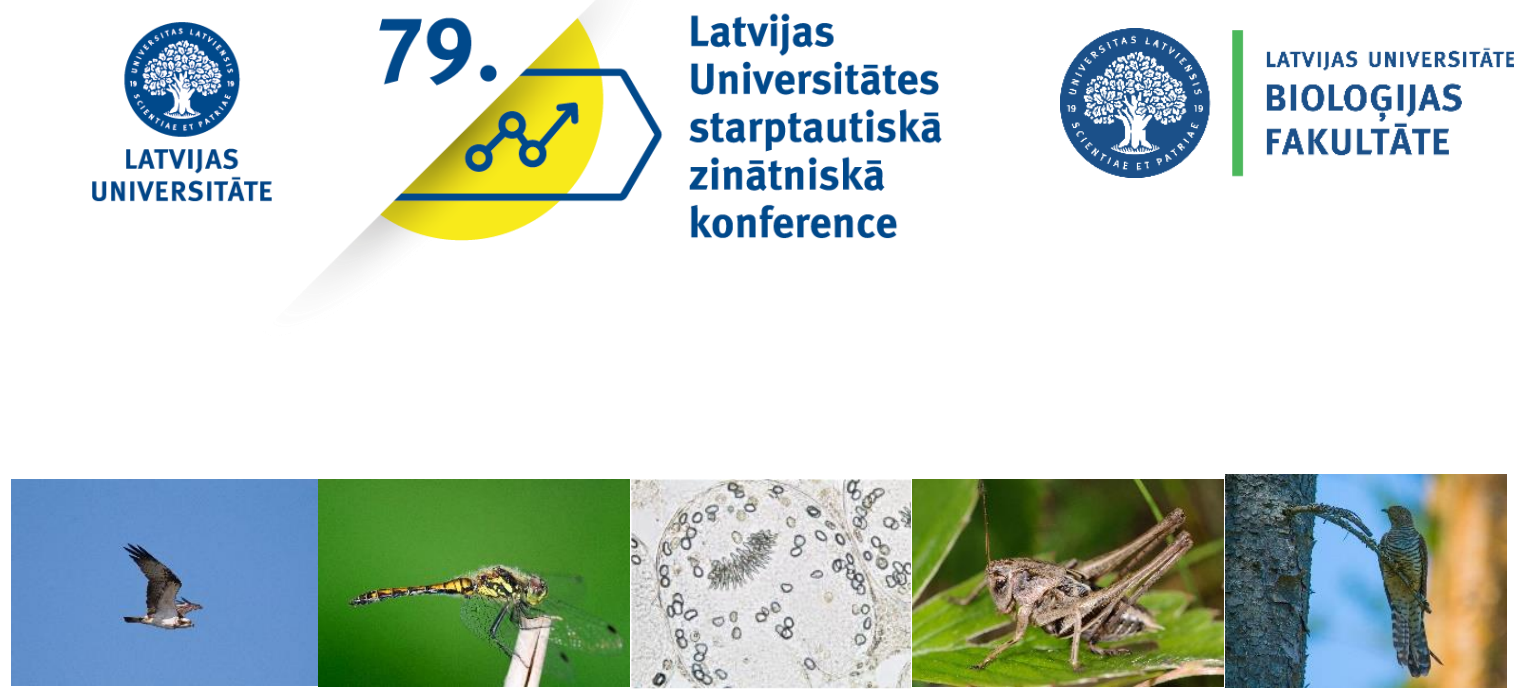

\author{
University of Latvia \\ 79th Scientific conference
}

\title{
Zoology and Animal Ecology
}

Abstract book

28 January 2021

Nature House University of Latvia

Riga, Latvia 

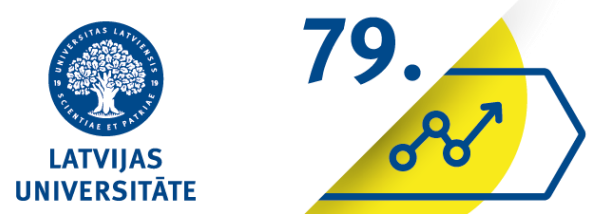

Latvijas

Universitātes

starptautiskā

zinātniskā

konference

\section{"Zooloğija un dzìvnieku ekoloğija"}

\section{Latvijas Universitātes 79. zinātniskā konference}

\section{Bioloğijas sekcija}

\section{Referātu tēžu krājums}

Biolog̣ijas fakultāte, Zoolog̣ijas un dzīvnieku ekologijas katedra

Latvijas Universitātes Dabas māja

2021. gada 28. janvāris

Rīga, Latvija

\section{Sastādīja: Gunita Deksne}

DOI: https://doi.org/10.22364/zde.2021

(C) Latvijas Universitāte, 2021

(C) Ainārs Auniṇš, Maira Mateusa, vāka foto 


\section{Bioloğijas sekcija / Biology section}

\section{Zooloǵijas un dzivnnieku ekoloǵijas apakšekcija / Zoology and animal ecology sub-section}

\section{Programma / Programme}

$$
28^{\text {th }} \text { of January, } 2021
$$

\begin{tabular}{|c|c|c|}
\hline \multicolumn{3}{|c|}{ Vadītājs/Chair: Asoc. prof. Ainārs Auniņš, Dr. biol. Gunita Deksne } \\
\hline $9.00-9.05$ & $\begin{array}{l}\text { Asoc. prof. Ainārs } \\
\text { Auniņs } \\
\text { Faculty of Biology, } \\
\text { University of Latvia }\end{array}$ & $\begin{array}{l}\text { Atklāšana } \\
\text { Opening }\end{array}$ \\
\hline \multicolumn{3}{|c|}{ Uzaicinātie ziṇojumi / Plenary session } \\
\hline 9.05-9.35 & $\begin{array}{l}\text { Prof: Arvīds } \\
\text { Barš evskis } \\
\text { Daugavpils University }\end{array}$ & $\begin{array}{l}\text { Vaboḷu bioloğiskā daudzveidība lietus mežos Filipīnās } \\
\text { Biological diversity of beetles in rain forests of Philippines }\end{array}$ \\
\hline $9.35-10.05$ & $\begin{array}{l}\text { Dr. biol. Viesturs } \\
\text { Kerus } \\
\text { Latvijas Ornitologijas } \\
\text { biedrība }\end{array}$ & $\begin{array}{l}\text { Ligzdojošo putnu atlanti: Latvijas putnu izplatības } \\
\text { pārmaiṇas Eiropas kontekstā } \\
\text { Breeding bird atlases: changes in the breeding bird distribution } \\
\text { in Latvia in the European context }\end{array}$ \\
\hline \multicolumn{3}{|c|}{ Mutiskie ziņojumi / Oral presentations } \\
\hline $10.05-10.20$ & Jānis Birzaks & $\begin{array}{l}\text { Spidillḳa Rhodeus amarus (Bloch, 1782) izplatības izmaiṇas } \\
\text { Latvijā } \\
\text { Distribution shifts of biterlling Rhodeus amarus (Bloch, 1782) in } \\
\text { Latvia }\end{array}$ \\
\hline $10.20-10.35$ & Uğis Piterāns & $\begin{array}{l}\text { Latvijas blakšu (Heteroptera) faunas izmainas 21. gadsimtā } \\
\text { Changes in Latvian true bug (Heteroptera) fauna during } 21^{\text {st }} \\
\text { century }\end{array}$ \\
\hline $10.35-10.50$ & Zanda Ozoliṇa & $\begin{array}{l}\text { Zoonotisko patogēnu sastopamība dzēlējodos un ērcēs } \\
\text { Latvijā } \\
\text { Occurrence of zoonotic pathogens in mosquitos and ticks in } \\
\text { Latvia }\end{array}$ \\
\hline 10.50-11.05 & \multicolumn{2}{|c|}{$\begin{array}{l}\text { Virtuālā kafijas pauze, diskusijas, stenda referāti } \\
\text { Coffee break, discussions, posters }\end{array}$} \\
\hline
\end{tabular}




\begin{tabular}{|c|c|c|}
\hline $11.05-11.20$ & Viesturs Ķerus & $\begin{array}{l}\text { Latvijas ligzdojošo putnu sarkanais saraksts } \\
\text { Red list of breeding birds of Latvia }\end{array}$ \\
\hline $11.20-11.35$ & Jurğis Šuba & $\begin{array}{l}\text { Latvijas vilku un lūšu ekoloğiskās kapacitātes un populācijas } \\
\text { pieauguma tempa vērtējums, izmantojot dažădus populāciju } \\
\text { dinamikas modelus } \\
\text { Assessment of the population growth potential of Latvian wolves } \\
\text { and lynxes using simple growth models }\end{array}$ \\
\hline $11.35-11.50$ & Valdis Pilāts & $\begin{array}{l}\text { Susuru monitorings Latvijā - rezultāti pēc pirmajiem } \\
\text { pieciem gadiem } \\
\text { Dormouse monitoring in Latvia - results after the first five years }\end{array}$ \\
\hline $11.50-12.05$ & Alekss Vecvanags & $\begin{array}{l}\text { Savvaḷas pārnadžu monitorings un to relatīvā skaita } \\
\text { novērtěšana, izmantojot kameru slazdus un mašīnmācišanās } \\
\text { pieeju } \\
\text { Monitoring of wild ungulates and estimation of relative } \\
\text { abundance using camera traps and machine learning approach }\end{array}$ \\
\hline $12.05-12.20$ & Antra Stīpniece & $\begin{array}{l}\text { Nomedīto ūdensputnu monitorings 2020. gadā } \\
\text { Monitoring of waterfowl hunting bags in } 2020\end{array}$ \\
\hline $12.20-12.35$ & Iveta Jakubāne & $\begin{array}{l}\text { Sabiedrības iesaiste invazīvo kailgliemežu sugu monitoringā } \\
\text { The public participation in the monitoring of invasive slug } \\
\text { species }\end{array}$ \\
\hline $12: 35-12: 45$ & \multicolumn{2}{|c|}{$\begin{array}{l}\text { Stenda referātu prezentācijas }(1 \text { min }) \\
\text { Short poster presentations (1 min) }\end{array}$} \\
\hline & Beatrise Jerina & $\begin{array}{l}\text { Toxoplasma gondii sastopamība meža cūkās (Sus scrofa) } \\
\text { Latvijā } \\
\text { Occurence of Toxoplasma gondii in wild boars (Sus scrofa) in } \\
\text { Latvia }\end{array}$ \\
\hline & Kristīne Greķe & $\begin{array}{l}\text { Dominamaria Iredale (Gastropoda: Assimineidae) } \\
\text { taksonomiskais novietojums, balstoties uz SEM un attēlu } \\
\text { analīzi } \\
\text { Taxonomic position of Dominamaria Iredale, } 1941 \text { (Gastropoda: } \\
\text { Assimineidae) as revealed by SEM and image analysis }\end{array}$ \\
\hline & Rūta Rozenfelde & $\begin{array}{l}\text { Latvijas taisnspārṇu fauna - izpētes vēsture un sugu } \\
\text { sastopamība mūsdienās } \\
\text { The Orthoptera fauna in Latvia - research history and species } \\
\text { occurrence today }\end{array}$ \\
\hline & Maira Mateusa & $\begin{array}{l}\text { Endoparazītu sastopamības pilsētas sunos Latvijā - pirmie } \\
\text { rezultāti } \\
\text { Presence of endoparasites in urban dogs in Latvia - preliminary } \\
\text { results }\end{array}$ \\
\hline
\end{tabular}




\begin{tabular}{|c|c|c|}
\hline & Larisa Kurenkova & $\begin{array}{l}\text { Hartinga strupastes Microtus hartingi (Arvicolinae, } \\
\text { Sumeriomys apakšǵints) inbrīdinga izpausme laboratorijas } \\
\text { apstāklos } \\
\text { Manifestation of inbreeding in Microtus hartingi (Arvicolinae, } \\
\text { subgenus Sumeriomys) vole under laboratory conditions }\end{array}$ \\
\hline 12.45-13.30 & \multicolumn{2}{|c|}{$\begin{array}{l}\text { Pārtraukums, diskusijas, stenda referāti } \\
\text { Break, discussions, posters }\end{array}$} \\
\hline $13.30-13.45$ & Indriķis Krams & $\begin{array}{l}\text { Plēsēja stress nomāe sistēmisko glikozi, izmantojot } \\
\text { serotonīna atkarīgo efektu } \\
\text { Predator stress represses systemic glucose use through } \\
\text { serotonin-dependent effect }\end{array}$ \\
\hline $13.45-14.00$ & Māris Munkevics & $\begin{array}{l}\text { Zirnekḷa smaržas izraisītas Drosophila melanogaster } \\
\text { k̦ermeṇa slāpekḷa un oglekḷa koncentrāciju izmaiṇas } \\
\text { Spider odors induce changes in body carbon and nitrogen } \\
\text { concentrations in Drosophila melanogaster }\end{array}$ \\
\hline $14.00-14.15$ & Elza Birbele & $\begin{array}{l}\text { Radiācijas ietekme uz sarkanblakšu Pyrrhocoris apterus } \\
\text { fluktuālo asimetriju } \\
\text { The effect of environmental radiation on fluctuating asymmetry } \\
\text { in the Red Firebug Pyrrhocoris apterus }\end{array}$ \\
\hline $14.15-14.30$ & Ilze Rubeniņa & $\begin{array}{l}\text { Prosotocus confusus apraksts Pelophylax esculentus } \\
\text { kompleksā un Rana temporaria Latvijā } \\
\text { Description of Prosotocus confusus in Pelophylax esculentus } \\
\text { complex and Rana temporaria from Latvia }\end{array}$ \\
\hline $14.30-14.45$ & $\begin{array}{l}\text { Alessandro Di } \\
\text { Marzio }\end{array}$ & $\begin{array}{l}\text { Pirmais ziņojums par leistisko odzi (Vipera berus, Linnaeus, } \\
\text { 1758) (Squamata: Serpentes: Viperidae) Kurzemē } \\
\text { First report of leucistic Common Adder (Vipera berus, Linnaeus, } \\
\text { 1758) (Squamata: Serpentes: Viperidae) in Kurzeme }\end{array}$ \\
\hline $14.45-15.00$ & \multicolumn{2}{|c|}{$\begin{array}{l}\text { Virtuālā kafijas pauze, diskusijas, stenda referāti } \\
\text { Coffee break, discussions, posters }\end{array}$} \\
\hline $15.00-15.15$ & Tatjana Zorenko & $\begin{array}{l}\text { Sociālā stresa ietekme uz Hartinga strupastes Microtus } \\
\text { hartingi priekšzobu patologisku augšanu eksperimentā } \\
\text { Effect of social stress on abnormal growth of the incisors of } \\
\text { Harting's vole Microtus hartingi under experimental conditions }\end{array}$ \\
\hline 15.15.-15.30 & Ronalds Krams & $\begin{array}{l}\text { Biotopa un sociālās apakšgrupas (kastas) ietekme uz zemes } \\
\text { kameņu (Bombus terrestris Linnaeus, 1758) mikrobiomu } \\
\text { The effect of habitat and caste on the microbiome composition of } \\
\text { the buff-tailed bumblebee (Bombus terrestris Linnaeus, 1758) }\end{array}$ \\
\hline $15.30-15.45$ & Otars Opermanis & $\begin{array}{l}\text { Vistu vanagu individuāla atpazīšana no dabā iegūtām } \\
\text { fotogrāfijām } \\
\text { Individual recognition of Northern Goshawks from images taken } \\
\text { in the wild }\end{array}$ \\
\hline
\end{tabular}




\begin{tabular}{|l|l|l|}
\hline 15.45-16.00 & L,ubova Baraškova & $\begin{array}{l}\text { Galvas smadzeṇu ġeometriskā morfometrija strupastu } \\
\text { taksonomijā } \\
\text { Brain geometric morphometry in vole taxonomy }\end{array}$ \\
\hline $16.00-16.15$ & Aivars Petriṇš & $\begin{array}{l}\text { Kādas ir iespējas mazā ērgḷa (Clanga pomarina } \text { L.) ligzdas } \\
\text { identificēšanā viena teritoriāla putna gadījumo } \\
\text { What are the possibilities of identifying the nest of the Lesser } \\
\text { Spotted Eagle (Clanga pomarina L.) in the case of a single } \\
\text { territorial bird }\end{array}$ \\
\hline $16.15-16.30$ & Uógis Kagainis & $\begin{array}{l}\text { Jauni pētījumu rezultāti malakoloğijā, balstoties uz } \\
\text { skenējošās elektronu mikroskopijas attēlu analīzi } \\
\text { New findings in malacology based on image analysis of scanning } \\
\text { electron microscopy }\end{array}$ \\
\hline $16.30-17 .--$ & $\begin{array}{l}\text { Noslēgums, diskusijas } \\
\text { Conclusions, discussions }\end{array}$ \\
\hline
\end{tabular}




\section{SATURS}

PLENARY SESION / PLENĀRIE ZIN̦OJUMI 9

BIOLOGICAL DIVERSITY OF BEETLES IN RAIN FORESTS OF PHILIPPINES 10 BREEDING BIRD ATLASES: THE CHANGES IN THE BREEDING BIRD DISTRIBUTION IN LATVIA IN THE EUROPEAN CONTEXT

PRESENTATIONS / MUTISKIE ZIṆOJUMI 12 DISTRIBUTION SHIFTS OF BITTERLING RHODEUS AMARUS (BLOCH, 1782) IN LATVIA 13 CHANGES IN LATVIAN TRUE BUG (HETEROPTERA) FAUNA DURING 21ST CENTURY 14 OCCURRENCE OF ZOONOTIC PATHOGENS IN MOSQUITOES AND TICKS IN LATVIA 15 RED LIST OF BREEDING BIRDS OF LATVIA 16 ASSESSMENT OF THE POPULATION GROWTH POTENTIAL OF LATVIAN WOLVES AND LYNXES USING SIMPLE GROWTH MODELS 17 DORMOUSE MONITORING IN LATVIA - RESULTS AFTER THE FIRST FIVE YEARS 18 MONITORING OF WILD UNGULATES AND ESTIMATION OF RELATIVE ABUNDANCE USING CAMERA TRAPS AND MACHINE LEARNING APPROACH 19 MONITORING OF WATERFOWL HUNTING BAGS IN 2020 20 THE PUBLIC PARTICIPATION IN THE MONITORING OF INVASIVE SLUG SPECIES 21 PREDATOR STRESS REPRESSES SYSTEMIC GLUCOSE USE THROUGH SEROTONIN-DEPENDENT EFFECT 22 SPIDER ODORS INDUCE CHANGES IN BODY CARBON AND NITROGEN CONCENTRATIONS IN DROSOPHILA MELANOGASTER

THE EFFECT OF ENVIRONMENTAL RADIATION ON FLUCTUATING ASYMMETRY IN THE RED FIREBUG PYRRHOCORIS APTERUS

DESCRIPTION OF PROSOTOCUS CONFUSUS IN PELOPHYLAX ESCULENTUS COMPLEX AND RANA TEMPORARIA FROM LATVIA 25

FIRST REPORT OF LEUCISTIC COMMON ADDER (VIPERA BERUS, LINNAEUS, 1758) (SQUAMATA: SERPENTES: VIPERIDAE) IN KURMEME 26 EFFECT OF SOCIAL STRESS ON ABNORMAL GROWTH OF THE INCISORS OF HARTING'S VOLE MICROTUS HARTINGI UNDER EXPERIMENTAL CONDITIONS 27

THE EFFECT OF HABITAT AND CASTE ON THE MICROBIOME COMPOSITION OF THE BUFF-TAILED BUMBLEBEE (BOMBUS TERRESTRIS LINNAEUS, 1758) 28 INDIVIDUAL RECOGNITION OF NORTHERN GOSHAWKS FROM IMAGES TAKEN IN THE WILD __ 29 BRAIN GEOMETRIC MORPHOMETRY IN VOLE TAXONOMY 30 WHAT ARE THE POSSIBILITIES OF IDENTIFYING THE NEST OF THE LESSER SPOTTED EAGLE (CLANGA POMARINA L.) IN THE CASE OF ONE TERRITORIAL BIRD 31 NEW FINDINGS IN MALACOLOGY BASED ON IMAGE ANALYSIS OF SCANNING ELECTRON MICROSCOPY 32 
OCCURRENCE OF TOXOPLASMA GONDII IN WILD BOARS (SUS SCROFA) IN LATVIA 34

TAXONOMIC POSITION OF DOMINAMARIA IREDALE, 1941 (GASTROPODA: ASSIMINEIDAE) AS REVEALED BY SEM AND IMAGE ANALYSIS 35

THE ORTHOPTERA FAUNA IN LATVIA - RESEARCH HISTORY AND SPECIES OCCURRENCE TODAY 36 PRESENCE OF ENDOPARASITES IN URBAN DOGS IN LATVIA - PRELIMINARY RESULTS 37 MANIFESTATION OF INBREEDING IN MICROTUS HARTINGI VOLE (ARVICOLINAE, SUBGENUS SUMERIOMYS) VOLE UNDER LABORATORY CONDITIONS 38 


\section{PLENARY SESION}

PLENĀRIE ZIN̦OJUMI 


\title{
BIOLOGICAL DIVERSITY OF BEETLES IN RAIN FORESTS OF PHILIPPINES
}

\author{
Arvīds Barševskis \\ Daugavpils University, Coleopterological Research Center, Latvia
}

E-mail: arvids.barsevskis@du.lv

The Philippines is one of 18 mega-biodiverse countries of the world, which contains twothirds of the earth's biodiversity and between $70 \%$ and $80 \%$ of the world's plant and animal species. The Philippines is also one of the world's biodiversity hotspots. Philippine Archipelago is an isolated group of 7000 small islands and it may harbour the greatest concentration of unique species per unit area in the world. Approximately 33 percent of its plants, 75 percent of its amphibians, 70 percent of its reptiles, and 44 percent of its birds are endemics and can be found only on the Philippine archipelago.

The diversity of beetles is much higher in the Philippine archipelago, which is still very poorly studied. Therefore, every year many hundreds new beetle species are discovered in the Philippine archipelago. The latest updated list of beetles in the Philippines was done by Ballentes in 2001 of which she listed a total of 7375 species from 1567 genera and 87 families. 5840 species or $79.2 \%$ are endemic to the Philippines. There are a very few data in literature about the distribution of Philippine beetles. For many species, no new records have been published since they were described. In recent years, some beetle families have been intensively studied, such as Cerambycidae. As an example of the intensity of coleopterological research in recent years, the author will use the genus Doliops. This genus is represented in the world's fauna by 73 taxa (species and subspecies), of which only one species is found outside the Philippine archipelago in the nearby Taiwan archipelago. In the last 10 years alone, 46 new taxa of this genus have been discovered and described, of which 31 taxa have been described by the author of this report. All species are found in very narrow distribution ranges, which can sometimes be around a separate mountain or even a separate slope. Together with the genera Pachyrhynchus, Metapocyrtus, Polycatus, etc., they form very specific mimicry complexes. These species complexes can be used as umbrella species complexes for the protection of natural rainforests. In the Philippines, the number of large-scale trees in rainforests are declining significantly, which is having a negative impact on beetle diversity. However, the biggest threat to beetle diversity is deforestation.

As Kummer wrote in 1992, the Philippines had 70\% forest cover of the country's total land area in 1900 to $50 \%$ in 1950 and to less than $19 \%$ by 1990 . In 1994, Serrant wrote that today, only about 6 million hectares (ha), or 20 percent of the total land area, remain under forest cover. Less than 1 million ha consists of virgin forest. Forest resources are being rapidly depleted (by an average of about 120,000 ha per annum) and there is a real prospect of Philippine forests being virtually eliminated within the next 20 years. In 2011, the official forestry statistics showed that the country had only around 7.2 million ha of forests. The Philippines lost around 10 million ha of its forests over the last seven decades, placing the country among those with the highest deforestation rates in the world.

To promote the development of coleopterological research in the Philippines, Daugavpils University coleopterologists initiated the establishment of the Coleopterological Research Center at the University of Mindanao (Davao, Philippines) and the establishment of the Philippine Coleopterological Network (PhilColNet). In collaboration with Philippine coleopterologists Dr. A.A.Cabras and Dr. M.N.Medina holds joint expeditions, joint seminars for students, and joint trainings for local coleopterologists every year. This will facilitate the development of coleopterological research in the Philippines. 


\title{
BREEDING BIRD ATLASES: THE CHANGES IN THE BREEDING BIRD DISTRIBUTION IN LATVIA IN THE EUROPEAN CONTEXT
}

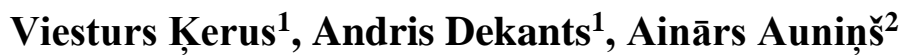

${ }^{1}$ Latvian Ornithological Society, LV-1010, Latvia; ${ }^{2}$ Faculty of Biology, University of Latvia, Latvia

E-mail: viesturs@lob.lv

Four country-wide breeding bird atlases were carried out in Latvia between 1980 and 2017. The mapping of the breeding bird distribution is based on a grid of squares of a set size. The goal of the study is to record all the breeding bird species in each of the squares. The data are then compiled in the bird species distribution maps. The comparison of these maps shows how the bird distribution has changed with changing conditions: political regimes, climate, land-use etc. However, the results should be interpreted with caution taking into account also changes in the atlas grids used, differences in survey coverage and knowledge on recording of species. To minimize the impact of these factors only sufficiently covered squares are compared when analysing the changes in bird distribution.

From 1980-1984 to 2000-2004 the distribution of 42 breeding bird species declined, 60 species increased but 81 species showed no significant change. From 2000-2004 to 2013-2017 52 species showed a decline in distribution, while the distribution of 38 increased and 97 species showed no significant change.

During this period also two European Breeding Bird Atlases have been carried out (around 1985-1989 and 2013-2017). When viewing the changes in bird distribution in Latvia in the European context it is possible to evaluate when the changes recorded in Latvia are likely to have been caused by factors operating on a large scale (e.g., climate change) and what are the prospects of the species to maintain or restore their populations in Latvia. 


\section{PRESENTATIONS}

\section{MUTISKIE ZIN̦OJUMI}




\section{DISTRIBUTION SHIFTS OF BITTERLING RHODEUS AMARUS (BLOCH, 1782) IN LATVIA}

\section{Jānis Birzaks}

University of Daugavpils, Latvia,

E- mail: Janis.Birzaks@du.lv

Bitterling Rhodeus amarus (Bloch, 1782) are Cyprinidae freshwater fish, which reproduction related with mussels Unio and Anodonta.

The bitterling is thermophilic species, their original distribution range was lower reaches of Black Sea and Azov Sea rivers (Danube, Dniester, Dnieper, Don, Kuban) as well as Caspian and Aral Sea rivers (Ural, Volga Amudarya) (Tsepkin, 1995). The earliest bitterling records from Central Europe in the period of $11-12$ th century are from areas with carp culture, it is probably that bitterling was distributed together with young carp. As the climate remains colder in $16-18$ th centuries their distribution range decreased, but begun increase in 19th century, reaching their current spread in Europe. In this period In Baltic sea basin bitterling was common in the rivers Vistula and Odra, also in East Prussia (now Kaliningrad province of Russia) (Van Damme et al, 2007). Towards North East species reported as common in the Nemuna rivers basin (current Lithuania and Belorussia territory) from the mid20th century (Zhukov, 1958), bit as rare species in the upper Daugava river (Russia Smolensk region) (Emelyanov and Schmidt 1951). In Estonia bitterling not found (Ojaveer, 2003). In the river Neva basin artificial popultaion of bitterling was found in hatchery fish ponds, which was the furthest finding of bitterling to North in the Baltic Sea basin, nowadays this population has disappeared (Kudersky, 2004).

In nowadays territory of Latvia bitterlig occurrence reported from the second half of 19th century (Kawall, 1858, Dybowski, 1862, Seidlitz, 1877). Bitterling considered as rare species up to 70s of 20th century, which occures in the rivers lower reaches of the Daugava and Lielupe rivers (Schneider, 1925, Mansfelds, 1936, Bērziňš, 1938, Николаев, 1953, Sloka, 1956) and Venta (Шапошникова, 1958). In 80s species found in the rivers Barta, Venta, Gauja and Salaca (Zvirgzds, 1987, Šternbergs, 1988, Aleksejevs and Birzaks, 2008).

From 90s found in $52(13,2 \%)$ rivers and $60(15,4 \%)$ lakes of Latvia. In period until year 2012 bitterling was widespread mainly in south west and central part of country by the furthest population to the East - $26^{\circ} 39^{\prime} 22^{\prime \prime} / 57^{\circ} 03^{\prime} 03^{\prime \prime}$. From the year 2013 species was found in upper part of the river Daugava in the river reach between $27^{\circ} 21^{\prime} 16^{\prime \prime} / 55^{\circ} 49^{\prime} 50^{\prime \prime}$ - $-26^{\circ} 37^{\prime} 53^{\prime \prime} / 55^{\circ} 52^{\prime} 29^{\prime \prime}$. Fish of several age groups have been found in population, indicating successful reproduction of bitterling in the East Latvia.

Fish migration upstream in the river Daugava is not possible due to HPS dams. It is possible that they has spread by migrating downstream from the territory of Russia or they number in population has increased and become visible. 


\section{CHANGES IN LATVIAN TRUE BUG (HETEROPTERA) FAUNA DURING 21ST CENTURY}

\section{Ugisis Piterāns}

The Latvian National Museum of Natural History, Latvia

E-mail: ugis.piterans@lndm.gov.lv

Although the history of Latvian true bug (Heteroptera) fauna research is rather extensive spanning from middle of $19^{\text {th }}$ up until end of $20^{\text {th }}$ century, the Latvian checklist has increased by approximately 120 species during the $21^{\text {st }}$ century. Much of this increase is no doubt because of increased efforts of local entomologists and much more available resources nowadays. But it is also noticeable that among recently registered species there are those that can be considered as "expansion species" - that were simply not present in Latvia during the period of prior entomologists. Such trend is noticeable also in other insect groups, for example dragonflies (Odonata), where there is strong evidence that number of species have expanded their range northwards in last 20 years - most likely as a response to changing climate. The aim of this study was to try to estimate the number of such northwards expanding species among true bugs registered in Latvia during $21^{\text {st }}$ century.

To get an overview of individual species distribution trends in our region, primarily the true bug checklists of Poland and Finland were analysed as they provided up to date distribution data for each country grouped by periods of 25 years. It was combined with other species distribution data available. After that species found in Latvia during period from year 2000 to 2020 were assigned to four groups: 1) obvious expansion species - species which also have arrived in Finland during the same period and also with very strong increase of observations in Poland during this period; 2) possible expansion species - usually species without obvious increase of observations in Poland, but often recorded in Finland for the first time during this period; 3) overlooked species - species present in Finland and Poland already before $21^{\text {st }}$ century; 4) insufficient data - status unclear. Results of this analysis show that 28 species (or 5,4\% of 516 current known species in Latvia) can be considered as obvious expansion species and 28 species are possible expansion species - so maximum number of species that have expanded their ranges northwards during $21^{\text {st }}$ and thus now are present also in Latvia century could be up to 56 species or $10,8 \%$ of all current known species in Latvia. That would be a similar proportion as seen in Odonata where 8 of 64 (or 12,5\%) species recorded in Latvia are with similar status.

Results show that there has been large number (60) of previously overlooked Heteroptera species that obviously were present here before but were recorded for first time only during $21^{\text {st }}$ century. So we can argue that Latvian Heteroptera fauna still not very well studied. There is also obvious and significant presence of species that only recently have expanded their ranges northwards. It corresponds with trends seen in other insect groups that are studied well in Latvia (for example Odonata and Lepidoptera) and could indicate that similar trends should be present also in other less studied insect groups. Further studies are needed to fully understand the impact of climate change on species assemblages in Latvia. 


\title{
OCCURRENCE OF ZOONOTIC PATHOGENS IN MOSQUITOES AND TICKS IN LATVIA
}

\author{
Zanda Ozoliṇa, Maija Selezṇova, Svetlana Cvetkova, Voldemārs Spuṇgís \\ Institute of Food Safety, Animal Health and Environment "BIOR", Latvia \\ E-mail: zanda.ozolina@bior.lv
}

According to The World Health Organization vector-borne diseases comprise around 17\% of all infectious diseases that account for considerable burden to public health and economic losses in every affected country. While usually mosquito and tick-borne pathogens are associated with tropical areas, occurrence of West Nile Fever and reintroduction of malaria in Southern Europe, as well as expansion of invasive Aedes albopictus in Central Europe in the last decades indicates that vectorborne diseases are becoming a problem of global importance. The aim of this study is to determine the prevalence of potentially harmful pathogens to human and animal health in Latvian mosquitoes and ticks.

From 2018 - 2020 a large countrywide study was conducted, and mosquito and tick samples were collected from 380 different sites in various habitats (meadows, roadsides, forest clearings, lake and riversides, urban areas etc.). Around 6000 mosquitoes were collected using BG-Sentinel traps, entomological nets and human landing collection. More than 2600 tick samples were collected by a drag-flag method in $200 \mathrm{~m}$ long transects. Geolocation data and habitat description was also noted. Tick and mosquito species were identified by morphological characteristics and all samples were tested for viruses, bacteria and parasites using validated molecular methods.

Overall, 25 mosquito and 3 tick species were identified - all of which may be vectors for various pathogens, however the vector competence differs. Notable findings are overwintering mosquito Anopheles maculipennis, which is known as a malaria vector and an invasive tick species Dermacentor reticulatus spreading northwards. No flaviviruses were detected in mosquitoes, however, single cases of Dirofilaria repens, Plasmodium juxtanucleare and Francisella-like endosymbionts were noted. Most common pathogens found in ticks were tick borne encephalitis virus (1.7\%), Anaplasma phagocytophilum (16.7\%), Borrelia spp. (56.0\%), spotted fever rickettsia (49.1\%), Francisella-like endosymbionts (17.2\%) and Babesia species (10.1\%). Presence of Coxiella burnetii and Toxoplasma gondii in ticks was not observed.

Based on the results of this study and already published articles on the topic, we conclude that there are some already established and circulating vector-borne pathogens in the native tick and mosquito populations and there is a risk of introducing new pathogens to the local competent vectors in the future. Data of this study will be used to create recommendations on monitoring, control and eradication measures in order to prevent invasion of exotic vector species in Latvia that may pose risks to the public health and animals. 


\section{RED LIST OF BREEDING BIRDS OF LATVIA}

\section{Viesturs Kerus ${ }^{1}$, Ainārs Auniṇš}

${ }^{1}$ Latvian Ornithological Society, Latvia; ${ }^{2}$ Faculty of Biology, University of Latvia, Latvia

E-mail: viesturs@lob.lv

The evaluation of the species' threat (extinction risk) status is traditionally compiled in the red books or red lists. Such lists let evaluate the population status in a country and to a certain extent help setting the priorities for conservation. The red list for Latvia has been compiled twice: in 1985 and 2000 (for birds). Since then bird populations have changed, the available information on them has greatly improved and also the criteria for development of such lists (set by IUCN) have changed. Therefore, a new red list is needed. We have evaluated the threat status of the breeding bird species as the first step of development of a new red list for all birds. According to the criteria by IUCN five breeding bird species can be classified as regionally extinct, 79 species $(36 \%$ of the total number of breeding species) are threatened, 15 (7\%) species are near threatened and 112 can be classified as least concern. 


\title{
ASSESSMENT OF THE POPULATION GROWTH POTENTIAL OF LATVIAN WOLVES AND LYNXES USING SIMPLE GROWTH MODELS
}

\author{
Jurğis Šuba ${ }^{1}$, Andreas Lindén ${ }^{2}$, Yukichika Kawata ${ }^{3}$ \\ ${ }^{1}$ Latvian State Forest Research Institute "Silava", ${ }^{2}$ Latvia; Natural Resources Institute Finland, \\ Finland; ${ }^{3}$ Kindai University, Faculty of Economics, Japan \\ E-mail: jurgis.suba@silava.lv
}

Conflicts between large carnivores and people are common due to livestock depredation and competition for game. Knowledge on local abundances of large carnivores and the potential for population growth are relevant matters for management and for ensuring wildlife-human coexistence in the long-term. Current conservation goals in Latvia do not specify the maximum abundance for wolves and lynxes, allowing potential for growth. However, both species are also managed by strictly regulated hunting or lethal control, which is planned adaptively according to their population state, in order to mitigate conflict situations.

Reported abundances of wolves and lynxes have increased during the last two decades, approaching the carrying capacity estimated in previous studies according to their population growth and annual harvest. Using additional data accumulated during the last decade, we re-investigated the growth rate and carrying capacity of wolves and lynxes in Latvia. We considered two alternative population growth models with potentially delayed density dependence: the Ricker model representing scramble competition and the Skellam model representing contest competition. For both species we found good support for the Ricker model, in wolf with exponentially increasing carrying capacities and a 1-2 year delay in the density dependence. We propose that increasing carrying capacities may be related to increasing populations of ungulate prey species.

This study has been conducted as part of a postdoctoral research project "Sub-population dynamics of grey wolf Canis lupus and Eurasian lynx Lynx lynx in Latvia and identification of depredation risk on livestock" (No. 1.1.1.2/VIAA/3/19/511) funded by European Regional Development Fund. 


\title{
DORMOUSE MONITORING IN LATVIA - RESULTS AFTER THE FIRST FIVE YEARS
}

\author{
Valdis Pilāts', Digna Pilāte ${ }^{2}$ \\ ${ }^{1}$ Nature Conservation Agency, Latvia; ${ }^{2}$ Latvian State Forest Research Institute "Silava", Latvia \\ E-mail: valdis.pilats@daba.gov.lv
}

In Latvia, four dormouse species have been recorded. Two of them - hazel dormouse Muscardinus avellanarius and forest dormouse Dryomys nitedula - are listed in Annex IV of EU Habitats Directive (HD). Therefore, annual monitoring of both species was commenced in 2016 as part of the national biodiversity monitoring programme. The monitoring aims to obtain data that would allow assessing the conservation status of the species and their habitats in the country, as well as preparing recommendations for measures to prevent adverse effects. Although a very short time has passed since the start of monitoring, some peculiarities both in the distribution and the dynamics of dormouse populations were noticed.

The nest-box method is used for the dormice survey, as it is equally suitable for collecting data on all four species. This method involves establishment of temporal small study plots with 5-15 nest-boxes in suitable habitats to detect species presence and finally get data on the species distribution. During the five-year period 781 nest-boxes in 96 sites all over the country have been installed. To collect data on the population dynamics, additional seven permanent study plots have been arranged. Each such study plot consists of at least 50 nest-boxes placed within a grid system at $50 \mathrm{~m}$ intervals between the boxes.

Although the network of nest-boxes covers nearly the entire country, in none of the plots the garden dormouse Eliomys quercinus was recorded. That is supporting the presumption that this species has vanished in Latvia. A new location of fat dormouse Glis glis has been discovered. The new site fits into the current range of the species - two isolated areas in the valleys of Daugava and Gauja Rivers. Notably, no overlapping of distribution areas of these three species was found, although theoretically it is possible. Forest dormouse is found exclusively in a very small area at the LatvianBelarusian border. The minimum convex polygon (MCP) is used to measure distribution area of this species every year. During the 5-year period, it varied from 494 to 1174 ha. Surveys with the nestbox method have confirmed the presence of hazel dormouse only in W and S Latvia but not in several sites with rather recent accidental observations of this species to the north from Daugava River.

The nest-box occupation both for forest and hazel dormouse has decreased in 2019-2020 compared to 2017-2018. It reached the lowest level in 2020. The main reason, most probably, is mild winters with increased dormice mortality. In some study plots, an adverse effect of forestry operations on nest-box occupation has been also recorded.

In Latvia, the conservation statuses both for forest and hazel dormouse were assessed as unknown within the Article 17 report under HD for the period 2013-2018. Unknown favourable reference values for species range and population were the main gaps to be able to assess the species' conservation status. Setting favourable reference values for the animal and plant species listed in the annexes of the HD, including both dormouse species, will be done within the recently commenced LIFE-IP LatViaNature project (2020-2028). 


\title{
MONITORING OF WILD UNGULATES AND ESTIMATION OF RELATIVE ABUNDANCE USING CAMERA TRAPS AND MACHINE LEARNING APPROACH
}

\author{
Alekss Vecvanags \\ Institute for Environmental Solutions, Latvia \\ E-mail: Alekss.Vecvanags@ videsinstituts.lv
}

Monitoring of wild ungulate populations is important for sustainability, wildlife conservation, and damage management for forestry and agriculture. Traditional methods for population abundance estimation and monitoring, such as grazing damage observation, pellet or snow track counts can take up large amounts of time, especially in large-scale and long-term studies, and requires trained experts. Due to their ease of use, non-intrusive nature and cost-effectiveness, camera traps have become a staple tool in wildlife monitoring and conservation efforts. But still, large scale studies can create sizeable amounts of data that can take a long time to analyze and can be prone to human error due to mental fatigue.

This study aimed to utilize modern computer vision object detection methods to aid in detection and estimating relative abundance of ungulates for monitoring purposes. Six camera traps were deployed in Rāmuḷi, Latvia from October $6^{\text {th }}$ till January $18^{\text {th }}$, generating an overall of 1657 images and 117 images. The convolutional neural network system YOLOv4 was benchmarked for detecting animals and their counts from camera trap images, with the results, then compared to expert counts to compare the effectiveness of these methods. 


\section{MONITORING OF WATERFOWL HUNTING BAGS IN 2020}

\section{Antra Stīpniece, Andris Stīpnieks, Māra Janaus, Toms Endziṇš}

University of Latvia, Institute of Biology, Latvia

E-mail: antra.stipniece@lu.lv

Since 1993 hunting bags have been checked during season opening weekend at 22 spots in Lakes Engure, Babīte and Liepāja and in Nag̣̣i fishponds. Since 2005 a group of volunteer hunters report species, sex and age composition of their bagged waterfowl. Since 2014 hunters send photos of bagged Bean Geese in order to identify subspecies. In 2019 a website www.nomeditie.org was launched providing opportunity to identify birds and also to send a report containing a photo. In 2020 Hunting Management Development Fund (MSAF) continued to support these activities. hunters.

Data about 343 hunting events were obtained during season opening and 442 were sent by

The opening season data show significant changes in species proportion in the hunting bag: in 2005-2020 rates of Coot, Garganey and Mallard have decreased and that of Gadwall increased. Bagged Gadwall data show Lake Babīte becoming a good moulting place for this species. Proportion of juvenile birds in the hunting bag (all season data) has decreased in 2016-2020 in comparison to 2005-2009 in Mallard, Teal and Wigeon, but not for Pintail and Goldeneye. According to legislation the beginning of the hunting season falls on the $2^{\text {nd }}$ Saturday of August. So, in different years the difference can be one week. In 2020 the earliest possible opening date coincided with cool spring. In several localities hunters reported unsuccessful season opening because birds were still flightless.

Possibility to receive photos reveals the species misidentification cases in hunter-sent data. The most often problem species were Gadwall, Goldeneye, Tufted duck.

A special leaflet was created in 2020 to advertise geese reporting. In total data about 140 Bean Geese (57,1\% juveniles), 83 Greater White-fronted (59,3\% juveniles) and 7 Greylag Geese (all adults) were received. 


\section{THE PUBLIC PARTICIPATION IN THE MONITORING OF INVASIVE SLUG SPECIES}

\section{Iveta Jakubāne', Santa Rutkovska ${ }^{2}$, Digna Pilāte ${ }^{3}$}

${ }^{1}$ Institute of Life Sciences and Technology, Daugavpils University, Latvia; ${ }^{2}$ Nature Conservation Agency, Latvia; ${ }^{3}$ State Forest Research Institute "Silava", Latvia

E-mail: iveta.jakubane@biology.lv

The current monitoring of invasive slug species (the Spanish slug Arion vulgaris and the blackheaded slug Krynickillus melanocephalus) has been performed in Latvia since 2018. The primary purpose of monitoring is to determine the distribution and degree of invasion of slugs on the whole territory of Latvia.

During the monitoring from 2018 to 2020, the 47 known Spanish slug localities were examined, where 185 sampling sites $(2 \times 10 \mathrm{~m})$ were established to evaluate the degree of invasion. The main results show that $A$. vulgaris occursin large numbers and forms stable populations. In recent years, the rapid invasion of this species has been observed. In 2018-2019, the invasion of Spanish slug was assessed as a very low (1-10 specimens $\left./ 20 \mathrm{~m}^{2}\right)$, whereas, in 2020 , due to the favourable weather conditions, the invasion was assessed from medium (21-51 specimens/20 $\mathrm{m}^{2}$ ) to high (51-100 specimens $/ 20 \mathrm{~m}^{2}$ ).

$K$. melanocephalus was monitored at four sites in natural habitats. In Latvia, the invasion of $K$. melanocephalus is evaluated as a medium. They also are found in large numbers and form stable populations. However, the investigation should be continued to assess the impact of slug species in their natural habitats.

The public participation in the monitoring of invasive slug species plays a crucial role in the identifying new localities of those species. The initiative of the Nature Conservation Agency to encourage the general public to report about large slug individuals resulted in more than 350 reports on Spanish slugs. The malacologists confirmed 34 new localities of A. vulgaris in 2020. The 108 localities of Spanish slug have been currently confirmed in Latvia. The species have also been found in natural habitats (forests and grasslands), as well as in or near specially protected nature territories.

The responsiveness of people in reporting large slug localities indicates Latvian general public's high activity and interest in identifying new areas affected by slug invasion. Therefore, the Nature Conservation Agency has developed a new public monitoring tool "Species Atlas" (within the project LIFE19 IPE/LV/000010 - LIFE-IP LatViaNature). This tool allows people to use datasheets and maps onspecies distribution and to fill the observation questionnaire. The public monitoring is also an essential source of data. It is expected that in the future its importance will increase not only in Latvia but also in the entire European Union. 


\title{
PREDATOR STRESS REPRESSES SYSTEMIC GLUCOSE USE THROUGH SEROTONIN-DEPENDENT EFFECT
}

\author{
Indriķis Krams ${ }^{1,2,3}$, Ronalds Krams ${ }^{3,4}$, Sergejs Popovs³, Māris Munkevics ${ }^{1,3}$, Tatjana \\ Krama $^{3,4}$, Priit Jõers 5 \\ ${ }^{1}$ Faculty of Biology, University of Latvia, Latvia; ${ }^{2}$ Institute of Ecology and Earth Sciences, University \\ of Tartu, Estonia; ${ }^{3}$ Department of Biotechnology, Daugavpils University, Latvia; ${ }^{4}$ Chair of Plant \\ Health, Estonian University of Life Sciences, Estonia; ${ }^{5}$ Institute of Molecular and Cell Biology, \\ University of Tartu, Estonia \\ E-mail: indrikis.krams@lu.lv
}

Neurophysiological stress conditions have been implicated in affecting systemic metabolic health, leading to the development of metabolic disorders like diabetes and obesity. We report that inducing predator stress, a condition similar to human psychological disorders, leads to a catabolic shift towards lipid utilization due to systemic inhibition of Akt protein kinase in wild Drosophila melanogaster. Administration of neurotransmitter serotonin precursor complements these induced metabolic dysfunctions. Our results show a direct link between psychological real-life stress conditions and impairment of systemic metabolism and introduce an excellent Drosophila model system for future studies of human mental disorders. The effects caused by stress and phenotype associations are important to inform conservation efforts. 


\title{
SPIDER ODORS INDUCE CHANGES IN BODY CARBON AND NITROGEN CONCENTRATIONS IN DROSOPHILA MELANOGASTER
}

\author{
Māris_Munkevics ${ }^{1,2}$, Ronalds Krams ${ }^{2,3}$, Sergejs Popovs², Indrikisis Krams ${ }^{1,2,4}$ \\ ${ }^{1}$ University of Latvia, Faculty of Biology, Latvia; ${ }^{2}$ Daugavpils University, Institute of Life Sciences \\ and Technology, Latvia; ${ }^{3}$ Estonian University of Life Sciences, Institute of Agricultural and \\ Environmental Sciences, Estonia; ${ }^{4}$ University of Tartu, Institute of Ecology and Earth Sciences, \\ Estonia \\ E-mail: maris.munkevics@du.lv
}

The presence of predators has a complex impact on the phenotypic development of prey. Developing organisms observe predation risk through different sensory modalities, and it may cause various physiological reactions. Earlier research has shown that predator presence during the larval stage of Drosophila melanogaster affects body mass and elemental composition, climbing speed, and the survival ability of adult flies under predation risk. However, it is unclear whether fruit flies detect spiders based on their odors alone or other predator cues.

In this study, we reared D. melanogaster in the presence of spider odors or with real spiders during the fly larval stage. We observed that the body mass of fruit flies decreased in either experimental groups compared with the control group. Odor and spider treatments did not significantly affect body carbon but increased body nitrogen. Subsequently, this reduced the carbon to nitrogen ratio in bodies of fruit flies reared with spider odors and spiders compared with control flies.

Overall, our results show that spider presence, whether real or merely olfactory, induces stoichiometric responses in the development of fruit flies. The stoichiometric responses did not differ between flies exposed to real predators and those exposed to spider odors only. These findings indicate that olfaction is an important modality of $D$. melanogaster in detecting predators. These results are important to improve the general stress paradigm and predicting how organisms sense environmental threats. 


\title{
THE EFFECT OF ENVIRONMENTAL RADIATION ON FLUCTUATING ASYMMETRY IN THE RED FIREBUG PYRRHOCORIS APTERUS
}

\author{
Elza Birbele, Indriķis Krams \\ University of Latvia, Faculty of Biology, Latvia \\ E-mail: elza.birbele@gmail.com
}

Environmental radiation has a complex impact on the development of animals. Measuring fluctuating asymmetry is an efficient approach to determine the levels of environmental stress. This non-experimental study aims to measure the fluctuating asymmetry of red firebugs (Pyrrhocoris apterus) collected from territories that vary in the intensities of environmental radiation in line with observing changes in several morphological traits and testing them as indicators of environmental stress.

Firebugs were collected in five major cities and one control area in Latvia. Measurements of fluctuating asymmetry were done on three segments of the antennae. The occurrence of wing ornament deformations was also assessed. A significant positive correlation between environmental radiation and fluctuating asymmetry of antennae was observed. Differences between fluctuating asymmetry in sexes of red firebugs were found, which may arise because of differences in resisting the radiation. Percentage wing ornament deformations increased until a specific radiation intensity and then decreased, most likely because of an increase in natural selection of the most asymmetric individuals.

Overall, the heightened fluctuating asymmetry in red firebugs was positively associated with the increased levels of environmental radiation. 


\title{
DESCRIPTION OF PROSOTOCUS CONFUSUS IN PELOPHYLAX ESCULENTUS COMPLEX AND RANA TEMPORARIA FROM LATVIA
}

\author{
Ilze Rubenina, Inese Gavarane, Ligita Mezaraupe, Evita Gravele, Mihails Pupins, Muza \\ Kirjusina \\ Daugavpils University, Institute of Life Sciences and Technology, Latvia \\ E-mail: ilze.rubenina@du.lv
}

European water (or green) frogs of the Pelophylax esculentus complex consists of two parental pool species: Pelophylax ridibundus $\times$ P. lessonae hybrids. The frog is widely distributed in western Palaearctic. The common frog also is known as Rana temporaria and inhabits Europe from the Pyrenees to the Urals and West Siberia. Several researchers in Europe have performed helminthological investigation for both frog species. However, there is a limited information available about one of the helminth species - Prosotocus confusus, which harbours the P. esculentus complex and $R$. temporaria in Latvia. Prosotocus genus comprises more than 25 species that infect frogs., Species identification is challenging as morphologically of $P$. confusus is similar to the parasite Pleurogenes median. Confocal laser scanning microscopy (CLSM) technique was used to obtain qualitative data for parasite's morphological structures.

In the present study, we performed a helminthological investigation of Pelophylax esculentus complex and Rana temporaria collected in 2018 - 2020 randomly in Latvia. In total, small intestine of 124 Pelophylax esculentus complex and 206 Rana temporaria were examined for the presence of Prosotocus genus parasites. Prosotocus confusus was found in seven P. esculentus complex and in one $R$. temporaria.

Description of the parasite including morphology and life cycle was based on obtained results from both frog species. CLSM and benzanthrone dye P7 was used to visualize the taxonomical keys of $P$. confusus. Parasite's invasion rates were calculated.

Obtained data showed, the benzanthrone dye is applicable for the parasite's detailed imaging of taxonomic keys by CLSM. P. confusus was found to be more prevalent in the $P$. esculentus complex.

This work was supported by State Education Development Agency No. LV-UA/2020/05. 


\title{
FIRST REPORT OF LEUCISTIC COMMON ADDER (VIPERA BERUS, LINNAEUS, 1758) (SQUAMATA: SERPENTES: VIPERIDAE) IN KURMEME
}

\author{
Alessandro Di Marzio \\ Riga Zoo, Latvia \\ E-mail: research@rigazoo.lv
}

Patterns and body coloration have multiple functions in animals, ranging from thermoregulation to mimicry or aposematism. Besides the normal color patterns, it is possible to observe individuals with numerous color variations; the most common are melanism, albinism, and leucism. Amongst the snakes melanistic individuals are the most commonly seen. Leucistic individuals present a pinkishwhite coloration, with a pigmented eye (dark or blue), while albinos usually have similar coloration but with an unpigmented, reddish eye. Albinos and leucistic individuals would appear to be more disadvantaged in nature, including potential problems with thermoregulation, blindness, and greater visibility to predation. Among European vipers, the Common Adder (Vipera berus) is the species with the highest number of albino individuals reported, mainly from northern Europe but with recent observations in Slovakia. In vipers, studies have attributed to the zigzag dorsal pattern a camouflaging and/or aposematic function and a lack of such a pattern in albino and leucistic specimens could increases their risk of being preyed upon.

On May 2020 a pink-colored individual of Common adder was found by local residents near their house, while they were taking a walk on the side of the P128 road near Kemeri National Park $\left(57.0686^{\circ} \mathrm{N}, 23.2878^{\circ} \mathrm{E}\right)$. The habitat in this area is characterized by Pinus sylvestris forests and bush vegetation, at a short distance from the beach and houses. The snake was observed among the vegetation on two consecutive days, displaying evident mobility problems. The animal was reported to Riga Zoo staff and transferred to the Reptilarium's facilities. Unfortunately, the snake could not be treated successfully and died in captivity two weeks after it was captured. Measurements were taken on the specimen, scale counts were taken, and scale patterns were described. The specimen (168 $\mathrm{mm}$ snout-vent length $+22 \mathrm{~mm}$ tail length $=190 \mathrm{~mm}$ total length; body weight $=3 \mathrm{~g}$ ), had a pink body coloration and a darkly pigmented eye.

Although several studies report alterations in the pholidosis and ventral scales in Common adder, our specimen presented values within the limits of the species. 


\section{EFFECT OF SOCIAL STRESS ON ABNORMAL GROWTH OF THE INCISORS OF HARTING'S VOLE MICROTUS HARTINGI UNDER EXPERIMENTAL CONDITIONS}

\section{Tatjana Zorenko}

Faculty of Biology, University of Latvia, Latvia

E-mail: tatjana.zorenko@lu.lv

The abnormal growth of the incisors and deformity of the upper incisors, as well as defects of the lower jaw, was found in voles Microtus hartingi lydius in laboratory conditions. It has been revealed, that incisor and mandibular defects of laboratory rats are associated with the expression of genes that affect the synthesis of PTHR1 peptides (Decker et al. 2008; Kanno et al. 2017). The epigenetic effect may indicate the action of environmental factors, including stress. We hypothesized that dental growth disorders may be the result of social stress. The stress may have been caused by a change in the voles lifestyle. Usually $M$. h.lydius voles create mated pairs (monogamy). In the experiment, polygynous groups were formed, consisting of a male and two related or alien females. A polygynous group negatively affects both survival and growth rates of the offspring and females. 


\section{THE EFFECT OF HABITAT AND CASTE ON THE MICROBIOME COMPOSITION OF THE BUFF-TAILED BUMBLEBEE (BOMBUS TERRESTRIS LINNAEUS, 1758)}

\section{Ronalds Krams ${ }^{1,2}$, Sergejs Popovs ${ }^{2}$, Māris Munkevics ${ }^{2,3}$, Dita Gudrā ${ }^{4}$, Kaspars Megnis ${ }^{4}$, Tatjana Krama ${ }^{1,2}$, Dāvids Fridmanis ${ }^{4}$, Indriķis Krams ${ }^{2,3,5}$}

${ }^{1}$ Estonian University of Life Sciences, Institute of Agricultural and Environmental Sciences, Estonia; ${ }^{2}$ Daugavpils University, Department of Biotechnology, Latvia; ${ }^{3}$ University of Latvia, Faculty of Biology, Latvia; ${ }^{4}$ Latvian Biomedical Research and Study Centre, Latvia; ${ }^{5}$ University of Tartu, Institute of Ecology and Earth Sciences, Estonia.

E-mail: ronalds.krams@gmail.com

Composition and stability of the gut microbiome are essential to maintain the bumblebee (Bombus) immune system and health. Although bumblebees are key pollinators in agricultural landscapes, little is known about how gut microbial communities respond to anthropogenic changes.

In this study commercially produced colonies of buff-tailed bumblebees (Bombus terrestris) were placed in three habitats. Whole guts of $B$. terrestris specimens were dissected from the body and analysed using $16 \mathrm{~S}$ phylogenetic community analysis. Significantly different bacterial community composition between the agricultural landscapes - apple orchards and oilseed rape (Brassica napus) fields, and forest meadows was observed. Differences in gut communities between the orchards and oilseed rape fields were nonsignificant. Bee-specific bacteria like Lactobacillus, Snodgrassella and Gilliamella dominated gut communities of $B$. terrestris specimens. In contrast, the guts of bumblebees from forest meadows were dominated by fructose-associated Fructobacillus. Bacterial communities of workers were the most diverse, while those of males and young queens were less diverse. Our results suggest that habitat quality, exposure to environmental microbes, nectar quality and land-use significantly affect gut bacterial composition in B. terrestris. 


\section{INDIVIDUAL RECOGNITION OF NORTHERN GOSHAWKS FROM IMAGES TAKEN IN THE WILD}

\section{Otars Opermanis, Imants Jakovḷevs}

Latvian Biomedical Research and Study Centre, Latvia; Latvian Ornithological Society, Latvia

E-mail: opermanis@gmail.com

We launched a long term population study of urban Northern Goshawks Accipiter gentilis in Riga City, Latvia. In addition to ringing of young birds at nests, we made an effort to photograph each adult individual present in the study area to enable subsequent image analysis and recognition of individuals based on observed head patterns. In order to assess possible error rate in such work we offered a special test to 34 ornithologists, both amateurs and professionals, and asked to perform similar recognition as in actual study. Participants were provided with 20 pairs of goshawk head images and they were asked to assess if each image pair represents the same or different bird. The correct answer was known as birds involved were either ringed or had various distinct phenotypic traits not visible on offered images. On average $82 \%$ of image pairs were classified correctly. We shall discuss factors that apparently affect error rate in recognition of goshawk individuals using images and the applicability of such method in ecological studies. 


\section{BRAIN GEOMETRIC MORPHOMETRY IN VOLE TAXONOMY}

\section{L,ubova Baraškova}

University of Latvia, Faculty of Biology, Latvia

\section{E-mail: lubova.baraskova@gmail.com}

The purpose of this work is to investigate the divergence of the brain by shape of three vole's taxa of "guentheri" group with geometric morphometric. The obtained data show that the sex as a factor does not affect the brain's shape of the studied taxa, which indicates a weak effect of the sex on morphological adaptation and variability of the brain structure in the selection process. Geometric deformities of the brain in all taxa are found. Analysis of canonical variations showed that all three taxa differ significantly, both laterally and dorsally. Comparing the taxa DFA lateral view are found differences in brain form, $M$. h. harting cerebellum hemisphere and brains hemisphere are expanded from above, while $M$. $h$. lydius have small olfactory bulbs. By dorsal view DFA $M$. $h$. harting have slightly longer olfactory bulbs than $M$. h. lydius. M. guentheri cerebellum hemisphere and worm are wider than the $M$. hartingi. The obtained data indicate that the divergence of $M$. guentheri is deeper, which is obviously related to the older isolation of this species by the mountain range "Anatolian diagonal". The isolation of the M. hartingi population occurred later by the Bosporus Strait, so the difference in brain shape is slightly less. 


\title{
WHAT ARE THE POSSIBILITIES OF IDENTIFYING THE NEST OF THE LESSER SPOTTED EAGLE (CLANGA POMARINA L.) IN THE CASE OF ONE TERRITORIAL BIRD
}

\author{
Aivars Petriņ̌š \\ Latvian Fund for Nature, Latvia \\ E-mail: aivars.petrins@lu.lv
}

In order to follow the changes in the Lesser Spotted Eagle population in Latvia, this species is actively monitored, which includes both visual observations and inspection of nests according to a classic methodology. On average only $64.73 \%$ of the population pairs nest annually (successfully or unsuccessfully). Other birds inhabit the nesting area as pairs without juveniles or as separate territorial birds.

In the assessment of nesting success, it is often necessary to look for signs of the population on the nest. An inhabited nest can be characterized by having regular visits by one bird or a couple during the season. A nest without any evidence of bird activity is considered uninhabited. A nest population assessment can be made if there is no juvenile in the nest. In order to identify the species that inhabit the nest an assessment is made of the nest decoration in combination with egg shells (unsuccessful nesting) and species-specific fallen feathers. If no signs of population can be detected on the nest, assessment difficulties arise in monitoring. Nest protection also requires data on the inhabited nest. Do little eagles always leave signs of their presence in populated nests?

An additional method to assess the population of the nests is the use of automatic cameras at the location of the nests. In order to find out whether and how often such nests are visited, the number and duration of visits was captured with automatic cameras or photo traps at 5 nests in 5 nesting stations in Auce and Tērvete counties in 4 seasons (2017-2020). It is important to note that a couple or a separate territorial bird can have a primary and spare nests. The birds living in the area in the given season decide which nest is primary and which is spare. One of the main features of a primary nest is its longevity and nesting times in it. During the study period, out of 5 nests, 2 turned out to be the main ones (A and B), but 3 were spare.

The species has nested 6 times in the main A nest (monitored for 20 years) and at least 2 times in the main B nest (monitored for 7 years).

The A nest was actively decorated by a couple in 2017. In the next three years no population was detected using the classic methodology. However, the automatic cameras fixed frequent visitations by one bird. In 2018 it was fixed on the nest 11 times, in 201919 times and in 202014 times.

Nest B was unpopulated according to the classic methodology in 2019, however the automatic camera detected 22 visits of the nest. In 2020, the couple actively decorated the nest.

It is possible that, in the case of a single territorial bird, the behavior of the male and female on the nest differs in terms of posture, activity and duration. If a pair is formed or it is forming, the behavior on the nest can be different - both with and without decorating the nest. It may depend on the stage of formation of the pair. The monitored A and B nests of the main status were inhabited and visited many times during the season, although there was no evidence of this according to the classic nest population assessment methodology. When inhabiting a main nest, spare nests are either not visited at all or only a few times earlier and later in the season. This research has shown that in cases where no physical evidence of population have been found on the nest, additional observations on the presence of birds in the area must be made. Nests inhabited by small eagles (regularly visited) may not show physical evidence of attendance and may not have other more populated nests. 


\title{
NEW FINDINGS IN MALACOLOGY BASED ON IMAGE ANALYSIS OF SCANNING ELECTRON MICROSCOPY
}

\author{
Uǵis Kagainis ${ }^{1,2}$, Kristīne Greḳe ${ }^{3}$, Dmitry Telnov ${ }^{1,4}$ \\ ${ }^{1}$ Institute of Biology, University of Latvia, Latvia; ${ }^{2}$ Faculty of Biology, University of Latvia, Latvia; \\ ${ }^{3}$ Latvian National Museum of Natural History, Latvia; ${ }^{4}$ Natural History Museum, Department of Life \\ Sciences, United Kingdom \\ E-mail: ugis.kagainis@lu.lv
}

In malacology, the scanning electron microscopy (SEM) is known as a powerful tool applied to analyse the external morphology and shell microstructure of meso- and microscopic specimens, in particular. Most often fine-structure traits are crucial in mollusc taxonomy and require for an observation using a high-resolution microscopy. In recent years, at the University of Latvia scanning electron microscopy SEM has been exploited in order to study various mollusc taxa from Wallacea and New Guinea. In this report, the most important findings from four independent studies of such analysis are briefly described.

Empty shells or amputated wet radulae of adult snails (Mollusca: Gastropoda) were chemically and ultrasonically cleaned before SEM. Specimens were placed on a carbon tape glued to the aluminium stubs with or without ion coating (Au $20 \mathrm{~nm}$ ). SEM images (micrographs) were taken using a Hitachi TM-3000 microscope.

High resolution was not only important for analysing qualitative traits but also for making precise measurements from the micrograph for numerical approval of the hypothesis. In this case the functional role of hair-like projections on the Japonia sp. shell. Micrographs obtained were all tree-dimensional projections and thus were more precisely interpreted when it came to describing a 3D structure and microscopic sculpture of the specimen (e.g., for diplommatinid snail taxa described new to science). However, shells widely differed in terms of suitability for chemical and ultrasonic cleaning - thinnest being the most fragile and complex to work with (e.g., Ferrissia sp.). A critical point drying and an ion coating both were strongly suggested to avoid charging artifacts visible in micrographs. Besides shells, also a soft-tissue samples (i.e., radulae of the Assimineidae and Cyclophoridae snails) were tested for electron beams and found useful for supporting taxonomically important diagnoses.

After some approbation individually adapted for each study it was possible to overcome methodological obstacles and exploit SEM as an irreplaceable tool for a wide range of malacology research at the University of Latvia. 
79th scientific conference of University of Latvia

Bioloy section, Zoology and Animal Ecology sub-section, 28th of January, 2021

\section{POSTERS}

\section{STENDA REFERĀTI}




\title{
OCCURRENCE OF TOXOPLASMA GONDII IN WILD BOARS (SUS SCROFA) IN LATVIA
}

\author{
Beatrise Jerina $^{1}$, Gunita Deksne ${ }^{1,2}$ \\ ${ }^{1}$ University of Latvia, Faculty of Biology, Latvia; ${ }^{2}$ Institute of Food safety, Animal health and \\ Environment BIOR, Latvia \\ E-mail: beatrise.jerina@gmail.com
}

Toxoplasma gondii is a zoonotic protozoan parasite, which can infect a wide range of warmblooded animals, including humans and cause toxoplasmosis. Infection occurs by ingesting parasite oocysts, found in raw and undercooked contaminated meat or excreted into environment with feces. T. gondii is one of the most important foodborne pathogens, causing an agricultural losses and consequently economic losses.

The wild boars (Sus scrofa) as an intermediate host of $T$. gondii are potential carrier of many diseases, including toxoplasmosis. The wild boars are widely distributed across the territory of Latvian and Europe. Due to destructive wild boars behavior in agricultural territories, the hunting was increased. As a result, the wild boars meat is more available for consumers that before.

The aim of this study was to determine the presence of $\mathrm{IgG}$ antibodies to Toxoplasma gondii in the meat juice of hunted wild boars in Latvia. The meat juice samples were collected from 383 wild boars in June 2019 until January 2020 in the territory of Latvia. No data about age and sex was available. All meat juice samples were analyzed using IDvet commercial enzyme-linked immunosorbent assays (ELISA) test. This indirect method uses the P30 antigen of $T$. gondii presence.

The results showed that apparent seroprevalence was $31 \%$ in wild boars population in Latvia, which means antibodies to $T$. gondii were detected in $118 / 383$ wild boar meat juice. This means that wild boars are still a potential source of Toxoplasma gondii in Latvia. Further studies are needed to establish risk factors. 


\title{
TAXONOMIC POSITION OF DOMINAMARIA IREDALE, 1941 (GASTROPODA: ASSIMINEIDAE) AS REVEALED BY SEM AND IMAGE ANALYSIS
}

\author{
Kristīne Greḳe ${ }^{1}$, Uǵis Kagainis ${ }^{2,3}$, Dmitry Telnov ${ }^{3,4}$ \\ ${ }^{1}$ Latvian National Museum of Natural History, Latvia; ${ }^{2}$ Faculty of Biology, University of Latvia, \\ Latvia; ${ }^{3}$ Institute of Biology, University of Latvia, Latvia; ${ }^{4}$ Natural History Museum, Department of \\ Life Sciences, United Kingdom \\ E-mail: k.greke@gmail.com
}

Dominamaria Iredale, 1941 is a genus of small to medium-sized terrestrial gastropods distributed exclusively on New Guinea and its satellite islands. Iredale (1941) erected Dominamaria within the Pseudocyclotidae Iredale, 1941 (currently valid as Assimineidae H. Adams \& A. Adams, 1856) purely on the base of conchiliological features i.e., structure of the shell and operculum. Fukuda \& Ponder (2003) moved Dominamaria to Cyclophoridae Gray, 1847 according to the illustrations of radula of two species published by Hedley (1894) and Benthem Jutting (1963), in both cases drawn using the optical microscope. Our team SEM-micrographed radulae of adult specimens representing about 10 Dominamaria species sampled from different localities in the Western New Guinea and Raja Ampat Islands. Radulae were amputated and chemically cleaned. Wet radulae were extracted and placed flat on the carbon tape with teeth up and coated with $20 \mathrm{~nm} \mathrm{Au}$ in ion coater. Samples studied in depth with Hitachi TM-3000 by analysing the SEM micrographs. As a result, we strongly support the placement of Dominamaria in Assimineidae by radular features, the main family- and genus-rank character of the Littoriniformes Pcelintsev, 1963. 


\title{
THE ORTHOPTERA FAUNA IN LATVIA - RESEARCH HISTORY AND SPECIES OCCURRENCE TODAY
}

\author{
Rūta Rozenfelde, Voldemārs Spuṇgis \\ University of Latvia, Faculty of Biology, Latvia \\ E-mail: ruta.rozenfelde@lu.lv
}

The knowledge of Orthoptera fauna in Latvia, like many other insect groups, is increasing over time. First published list of Orthoptera dates back to 1778, when J. B. Fischer listed 9 orthopteroid species supposedly present in former territory of Livonia. Later, J. H. Kawall increased this number to 23 species, specifying the territory to Kurland (Kurzeme). After a long pause, the faunistic research of Orthoptera bloomed when the famous orthopterologist K. Princis worked in Latvia un 1930's and 1940's. He published a thorough review of Latvian Orthoptera in 1943, where he described 42 species that were present in Latvia at the time, with remarks on their distribution and occurrence, as well as potential species.

Today, with changes in climate and increased research effort in the last two decades, new species have been recorded in Latvia since the last review of K. Princis. For many species the taxonomy, occurrence and knowledge of distribution and ecology has changed as well. Therefore, there is a need for an updated Orthoptera list. Here, the occurrence of 50 species mentioned in literature is revised and reduced to 47 species. Taxonomical updates are implemented, and new knowledge of occurrence is presented.

At the moment, there is no existing monitoring programme for any particularly protected species or Orthoptera species diversity overall in Latvia, and the research effort is fragmented. But from this research, it is clear that grasshoppers are good indicators for dune, fen and grassland habitat quality. Climate warming could be the possible explanation to new arriving species in Latvian Orthoptera fauna. 


\title{
PRESENCE OF ENDOPARASITES IN URBAN DOGS IN LATVIA - PRELIMINARY RESULTS
}

\author{
Maira Mateusa ${ }^{1,2}$, Zanda Ozoliṇa ${ }^{1}$, Maija Selezņova1, Gunita Deksne ${ }^{1,3}$ \\ ${ }^{1}$ Institute of Food safety, Animal health and Environment "BIOR", Latvia; ${ }^{2}$ Faculty of Veterinary \\ medicine, Latvia University of Life Sciences and Technologies, Latvia; ${ }^{3}$ Faculty of Biology, \\ University of Latvia, Latvia \\ E-mail: maira.mateusa@bior.lv
}

Companion animals, such as dogs could be a potential source of zoonotic diseases. Previous studies shows that dogs may carry over 60 different zoonotic pathogens including important food borne parasites as Giardia duodenalis, Cryptosporidium spp. and Echinococcus spp. Endoparasites mainly are shed by faeces and may contaminate the environment as well as animal fur. The aim of present study was to determine occurrence of endoparasites in dogs from urban areas in Latvia.

During from August till December of 2020, 88 faecal samples from dogs of urban areas together with questionnaires were submitted on voluntarily bases by dog owners. Questionnaire contained information about dogs breed, age, sex, walking area preferences and activities and deworming practice. All fecal samples were tested by standard McMaster technique, egg sedimentation technique and fluorescent staining technique (Aqua-Glo ${ }^{\mathrm{TM}} \mathrm{G} / \mathrm{C}$, Waterborne INC, USA).

The overall prevalence of endoparasites in dogs was observed $16.0 \%$ (95\% CI 9.0-25.3). A total of five parasite genera were observed with highest prevalence for G. duodenalis $(12.5 \%)$, following by Cryptosporidium spp. (6\%), Toxocara canis, Uncinaria stenocephala and Isospora spp. (1.1\% each). Dogs, which were dewormed once a year had significantly $(\mathrm{p}=0.026)$ higher prevalence of endoparasites $(27.3 \%, 95 \%$ CI 13.3-45.5) compared to that observed in dogs which were dewormed twice per year $(7.7 \%, 95 \%$ CI 1.6-20.9).

Preliminary results indicates that dogs from urban areas in Latvia carry endoparasites with zoonotic potential and may be a source of infection for humans.

This study was funded by the European Regional Development Fund "1.1.1.2. "Post-doctoral research aid" "One Health" multidisciplinary approaches for epidemiology and prevention of selected parasitic zoonosis (OMEPPAZ), (1.1.1.2/VIAA/1/16/204) and is also part of "MEmE: Multi-centre study on Echinococcus multilocularis and Echinococcus granulosus s.l. in Europe: development and harmonisation of diagnostic methods in the food chain". 


\title{
MANIFESTATION OF INBREEDING IN MICROTUS HARTINGI VOLE (ARVICOLINAE, SUBGENUS SUMERIOMYS) VOLE UNDER LABORATORY CONDITIONS
}

\author{
Larisa Kurenkova \\ University of Latvia, Faculty of Biology, Latvia \\ E-mail: larisakurr@gmail.com
}

The role of inbreeding in population biology is not well defined yet, as it can bring both positive and negative consequences. The goal of current research was to define reaction to inbreeding in two subspecies of $M$. harting $i$ vole under laboratory conditions. Harting's vole is a convenient model object to study the link between inbreeding and reproductive strategy. In $M$. $h$. hartingi, the tendency to reproduce successfully in communal groups might have caused the increase in inbreeding rates and moreover the ability to overcome negative effects of it. Animals exhibit high reproduction rates, stable litter size and low offspring mortality, despite being kept in the laboratory for many generations.

It was proven that attitude on inbreeding in voles was uneven: European subspecies $M . h$. hartingi does not avoid inbreeding at all; $M$. $h$. lydius exhibits stronger negative effects when placed to copulate with close relatives, which results in high offspring mortality rates and even in mate rejection.

A rare pathological condition is observed in Harting's vole - unrestrained incisor growth, which could be the consequence of homozygosity increasing in the laboratory population.

Results of current research have shown that both subspecies are able to distinguish between smells of relatives and unfamiliar individuals; both males and females tend to choose unfamiliar partners over relatives. 